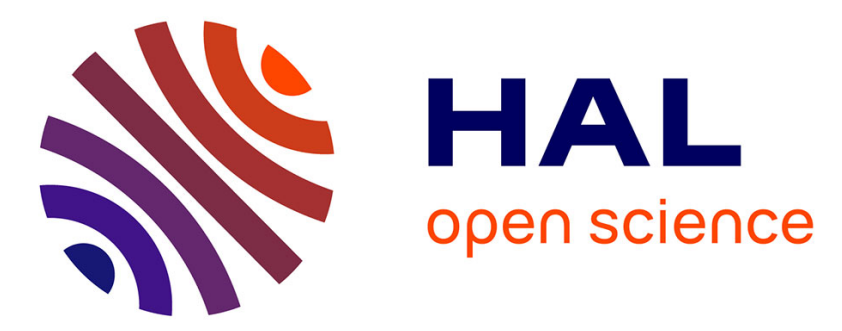

\title{
Assessment of the efficiency of three sampling methods for the recovery of soil charcoals in tropical anthropogenic sites
}

Stéphanie C Bodin, Thomas Feiss, Jean-François Molino, Laurent Bremond

\section{- To cite this version:}

Stéphanie C Bodin, Thomas Feiss, Jean-François Molino, Laurent Bremond. Assessment of the efficiency of three sampling methods for the recovery of soil charcoals in tropical anthropogenic sites. Quaternary International, 2021, 595, pp.145-154. 10.1016/j.quaint.2021.04.023 . hal-03208693

\section{HAL Id: hal-03208693 \\ https://hal.science/hal-03208693}

Submitted on 27 Apr 2021

HAL is a multi-disciplinary open access archive for the deposit and dissemination of scientific research documents, whether they are published or not. The documents may come from teaching and research institutions in France or abroad, or from public or private research centers.
L'archive ouverte pluridisciplinaire HAL, est destinée au dépôt et à la diffusion de documents scientifiques de niveau recherche, publiés ou non, émanant des établissements d'enseignement et de recherche français ou étrangers, des laboratoires publics ou privés.

\section{(ㅇ)(1) $\$$}

Distributed under a Creative Commons Attribution - NonCommercial - NoDerivatives 44.0 


\section{Assessment of the efficiency of three sampling methods for the recovery of soil charcoals in tropical anthropogenic sites}

Stéphanie C. Bodin*1,2 ${ }^{\text {Thomas Feiss }}{ }^{3}$, Jean-François Molino ${ }^{2}$, and Laurent Bremond ${ }^{1,4}$

${ }^{1}$ ISEM, Université Montpellier, CNRS, EPHE, IRD, Montpellier, France

${ }^{2} \mathrm{AMAP}$, IRD, CIRAD, CNRS, INRA, Université Montpellier, Montpellier, France

${ }^{3}$ Université de Lorraine, AgroParisTech, INRAE, UMR 1434 SILVA, Nancy, France

${ }^{4}$ École Pratique des Hautes Études, PSL University, Paris, France

Institut des Sciences de l'Évolution (ISEM)

UMR 5554 | Université de Montpellier | CNRS | IRD | EPHE

Place Eugène Bataillon | Cc 065

34095 Montpellier cedex 05 | France

s.bodin90@gmail.com

\section{Abstract}

The recovery and identification of wood charcoals from soil not associated to archaeological excavation is called pedoanthracology. Researchers in this field use different sampling methods, and only one study, in a temperate context, has compared their efficiency so far. In this paper, we compare the efficiency of three sampling methods on charcoal concentration ( $>4 \mathrm{~mm}$ ) and on taxonomic representativeness in a tropical environment for the first time. These methods are pit sampling, auger sampling and opportunistic handpicking of charcoal on tree uprooted mounds or in the soil excavated during the digging of a pit. Our results suggest that the two digging methods (pit and auger) allow to recover similar charcoal concentrations whatever the site and the depth under consideration. But as expected, the charcoal concentration of a site depends on its history (e.g. type of activity). We also show that the estimation of the minimal sampling effort required to obtain taxonomically representative assemblages, in terms of number of charcoals and of auger samplings, varied greatly depending on the site and on the presence of overrepresented taxa. Finally, our results show that auger cores were often monospecific (34\%). Nevertheless, they allowed to recover different taxa from the pit method, with 18 to $21 \%$ of the taxa exclusive to the first method and 30 to $40 \%$ of the taxa exclusive to the second one in the sites under consideration. Charcoals from opportunistic handpicking also allowed to improve the taxonomic diversity of the whole assemblage of a site with 5 to $15 \%$ of the taxa being exclusive to this method. The three methods are therefore complementary and we suggest to use the three of them to obtain the best taxonomic diversity in an anthracological assemblage and to overcome the specific biases of each method. With this study, we hope that we will help tropical (pedo)anthracologists to optimize charcoal sampling in anthropogenic sites were the sampling design cannot benefit from archaeological excavations.

Key words: Pedoanthracology - Sampling design - Tropical forest - Rarefaction curves Representativeness 


\section{Introduction}

Anthracology and pedoanthracology are sister archaeobotanical specialties which are used for the reconstruction of past ligneous vegetation through the identification of wood charcoal. The former is in close relation with archaeology since wood charcoals are sampled in known archaeological contexts (Chabal 1997; Heinz and Thiébault 1998; Dotte-Sarout 2017; Bachelet and Scheel-Ybert 2017), whilst the latter deals with soil charcoals not associated to archaeological units (Thinon 1978; Carcaillet and Thinon 1996; Scheel-Ybert et al. 2003; Di Pasquale et al. 2008; Talon 2010; Touflan et al. 2010; Nelle et al. 2013). The reliability of anthracological assemblages to reconstruct past ligneous environments has been demonstrated and the representativeness of these assemblages is the subject of an abundant literature (Badal Garcia 1992; Chabal et al. 1999; Scheel-Ybert 2002; ThéryParisot et al. 2010; Chrzazvez et al. 2014; Dotte-Sarout et al. 2015). Nevertheless, studies focusing on the efficiency of the sampling protocols are nearly inexistent, although this is a central issue concerning the representativeness of pedoanthracological assemblages. While anthracological sampling protocols 'guided' by the presence of archaeological deposits have been optimized (Chabal et al. 1999), pedoanthracological sampling schemes vary greatly among specialists and, to our knowledge, only one study has addressed this issue (Feiss et al. 2017). Two methods can be used for the systematic sampling of soil charcoals: pit sampling and auger sampling. The first one, which is the most used, consists in sampling soil volumes (usually $10 \mathrm{~L}$ or $10 \mathrm{~kg}$ ) along a soil profile in layers respecting the pedological horizons (Carcaillet and Thinon 1996; Dutoit et al. 2009; Feiss et al. 2017) or in artificial layers of about $10 \mathrm{~cm}$ in the tropics where soils horizons (oxisols) are less distinct (Scheel-Ybert et al. 2003; Hubau et al. 2012; Fernandes Caromano et al. 2013; Morin-Rivat et al. 2014; 2016; Dotte-Sarout et al. 2015). The dimensions of the pits vary among the studies and can take the form of large trenches of $1 \times 2 \mathrm{~m}$ wide (Scheel-Ybert et al. 2003; Di Pasquale et al. 2008) or small test-pits of $0.5 \mathrm{~m} \times 0.5 \mathrm{~m}$ or $1 \times 1 \mathrm{~m}$ wide (Dotte-Sarout et al. 2015; Morin-Rivat et al. 2016). The second method, auger sampling, is rarely used alone, i.e. without the pit sampling method (Vleminckx et al. 2014; Feiss et al. 2017). It is often restricted to prospection, i.e. to assess the depth of charcoal layers and the abundance of charcoals, which helps to determine the location for digging a pit (Tardy 1998; Hubau et al. 2012; 2013; Bourland et al. 2015; Dotte-Sarout and Kahn 2017) or to supplement a pit sampling in the deepest layers (Scheel-Ybert et al. 2003). Here again, the number of auger cores and the sampling design differ greatly depending on the environment and the aim of the study. In tropical regions, it is particularly important to develop effective sampling methods because field access is often difficult and environmental constraints are high, therefore sites cannot be easily revisited to supplement an insufficient sampling.

In this paper, we compare the efficiency of three sampling methods in a tropical environment for the first time, along the lines of the comparative study by Feiss et al. (2017) in a temperate environment. The three methods are auger sampling, pit sampling (digging methods) and opportunistic handpicking of charcoals during excavations or on uprooted tree mounds. This latter method can be used to prospect sites of interest (Tardy 1998) and as such, it is interesting to estimate its potential in terms of taxonomic coverage.

Specifically, we address the following questions:

1) is one of the two digging methods more efficient than the other for the recovery of soil charcoals?

2) do the site and sampling depth influence the amount of charcoal retrieved with each digging method?

3) do any of the three methods yield assemblages with better taxonomic richness? 
4) do they require the same sampling effort?

\section{Material and methods}

\subsection{Study area}

The fieldwork took place in the Nouragues Natural Reserve, central French Guiana, in 12 sites located near the two base camps 'Saut Pararé' $\left(4^{\circ} 02^{\prime} \mathrm{N}-52^{\circ} 41^{\prime} \mathrm{W}\right)$ and 'Inselberg' $\left(4^{\circ} 05^{\prime} \mathrm{N}-52^{\circ} 41^{\prime} \mathrm{W}\right)$. The prospected sites displayed different patterns of past human occupation in terms of vegetation structure and composition and in terms of archaeological evidences (earthworks, potsherds associated with charcoals, dark earths). Sites 1 and 5 are in Lasiacis thickets, site 9 is in a liana forest, site 7 is at the limit between a Lasiacis thicket and a liana patch and the remaining sites are under forest cover. Site 3 corresponds to a circular anthropogenic ditch circling a hilltop, a type of archaeological earthwork common in French Guiana. Table 1 summarizes the main features of the sites. See also Bodin et al. (2020) for additional information on site location.

\subsection{Sampling methods}

The sampling protocol was formerly described in Bodin et al. (2020). Despite the presence of archaeological artefacts (potsherds) and earthworks in several sites, our approach is pedoanthracologic because the recovery of charcoal fragments did not benefit from archaeological excavations. In sites 1 to 9 , we dug $80 \times 80 \mathrm{~cm}$ pits in which we collected $10 \mathrm{~kg}$ of soil in each $10-\mathrm{cm}$ depth layer. We also collected charcoal fragments by hand in the soil excavated during the digging process. Second, in sites where charcoals were abundant enough in the pit (at least a dozen of fragments), we sampled with a soil auger along transects centered on the pit in a 1-ha surface (Fig. 1), except for site 3 where we sampled at several points in the ditch. The objective with auger cores was to cover a larger area to better catch taxonomic diversity at the stand scale. The number of auger samples depended on site constraints such as vegetation thickness (pseudo-bamboos in site 1 and lianas in site 9 are hard to penetrate) and the presence of potential archaeological artifacts detected by magnetic anomalies (site 8). The sampling depth depended on the depth of the bedrock. For lack of time, the pits at sites 10 to 12 were not sampled, nor were sites 11 and 12 with any digging method. Finally, on sites 9 to 12 we looked for charcoals on all uprooted tree mounds present in the 1-ha surface centered on the pit. This last method was chosen because it was a quick way to obtain qualitative information on sites that we did not have time to fully investigate. For sites 1 to 8 , searching for charcoals in soil excavated during the digging of the pit is considered to be similar as searching on an uprooted tree mound because it is opportunistic. The different sampling methods applied for each site are showed in Table 1.

Table 1: history and main vegetation type of the sites investigated and number of samples for each sampling method applied (after Bodin et al. 2020).

\begin{tabular}{|l|l|l|l|l|l|}
\hline Site & History & Vegetation & $\begin{array}{l}\text { Number of pit } \\
\text { profile samples } \\
\text { each 10-cm depth, } \\
\text { (max. depth in cm) }\end{array}$ & $\begin{array}{l}\text { Number of auger } \\
\text { cores } \\
\text { (max. depth in cm) }\end{array}$ & $\begin{array}{l}\text { Number of tree uprooting } \\
\text { mounds/Excavated soil } \\
\text { investigated for charcoal }\end{array}$ \\
\hline 1 & Anthropized & Lasiacis thicket & $6(60)$ & $20(80)$ & $0 / 1$ \\
\hline 2 & Anthropized & Forest & $3(30)$ & $26(90)$ & $0 / 1$ \\
\hline 3 & Anthropized & Forest & $6(50)$ & $16(130)$ & $0 / 1$ \\
\hline 4 & $\begin{array}{l}\text { Non- } \\
\text { anthropized }\end{array}$ & Forest & $5(50)$ & 0 & $0 / 0$ \\
\hline 5 & $\begin{array}{l}\text { Non- } \\
\text { anthropized }\end{array}$ & Lasiacis thicket & $4(40)$ & 0 & $0 / 0$ \\
\hline 6 & $\begin{array}{l}\text { Potentially } \\
\text { anthropized }\end{array}$ & Forest & $5(50)$ & $23(60)$ & $0 / 1$ \\
\hline
\end{tabular}




\begin{tabular}{|l|l|l|l|l|l|}
\hline 7 & Anthropized & $\begin{array}{l}\text { Lasiacis } \\
\text { thicket/liana } \\
\text { forest }\end{array}$ & $5(50)$ & 0 & $0 / 1$ \\
\hline 8 & Anthropized & Forest & $4(40)$ & $6(80)$ & $17(60)$ \\
\hline 9 & Anthropized & Liana forest & $7(70)$ & $16(60)$ & $9 / 1$ \\
\hline 10 & $\begin{array}{l}\text { Non- } \\
\text { anthropized }\end{array}$ & Forest & - & - & $11 / 0$ \\
\hline 11 & Anthropized & Forest & - & - & $15 / 0$ \\
\hline 12 & $\begin{array}{l}\text { Non- } \\
\text { anthropized }\end{array}$ & Forest & - & $3 / 0$ \\
\hline
\end{tabular}

117

\subsection{Charcoal extraction and identification}

Soil samples from pit profiles and auger cores were water-sieved in the field to recover charcoal fragments in a 4-mm mesh, a suitable size for charcoal identification, especially in tropical areas (Chabal et al. 1999; Scheel-Ybert 2001). Charcoals were identified with the help of an electronic identification key (Bodin et al. 2019), the InsideWood online database (Wheeler 2011), specialized literature (Détienne et al. 1982; Détienne and Jacquet 1983; Scheel-Ybert and Gonçalves 2017) and reference collections of charred wood from Brazil and French Guiana (Scheel-Ybert 2016).

\subsection{Testing the effects of sampling method, sampling depth and site on charcoal} concentration

The sites considered for statistical analysis were those which were sampled with the same methods, i.e. sites 1, 2, 3, 6, 8 and 9. Sites 4 and 5 did not provide any charcoal fragment. We first tested the correlation between the number of taxa and the number of charcoal fragments using a Spearman test. The idea here was to determine whether we could discuss taxonomic richness given the charcoal richness. We then expressed the charcoal concentration as the total number of charcoal pieces per litre of sieved sediment (from pits and augers) to allow for comparison between all sites.

We tested the effect of the sampling method (pit vs. auger cores) on charcoal concentration using a Wilcoxon test. We then tested the effect of sampling depth and of site on charcoal concentration using a Kruskal-Wallis test and performed a Conover post hoc test from the PMCMRplus R package (Pohlert 2020) with a holm correction whenever significant.

Finally, we tested the effect of depth and of site on each method using Friedman tests: sites 1, 2, 3, 6, 7, 8 and 9 were considered for the pit method and sites 1, 2, 3, 6, 8, 9 and 10 were considered for the auger method (Table 1). In each case, comparisons were made for the same sampling depths, i.e. down to the $30 \mathrm{~cm}$ level when pits were included and down to the $60 \mathrm{~cm}$ level when comparisons were made for the auger method only, as we dug deeper in the soil with the auger (Table 1). We used the exact all-pairs comparisons test for unreplicated blocked data (Eisinga et al. 2017) from the PMCMRplus R package when the Friedman tests were significant.

\subsection{Determining the minimal sampling effort required to obtain a representative assemblage}

To determine the minimal number of charcoal fragments and the minimal number of auger cores required to obtain a representative assemblage of the floristic diversity, we followed the procedure described in Chao et al. (2014). We established individual-based rarefaction curves of the richest sites (i.e. 1, 2, 3, 9) for each sampling method and sample-based rarefaction curves using the iNEXT function from the iNEXT package (Hsieh et al. 2016). Individual-based curves represent the number of taxa as a function of the number of identifiable charcoal fragments (i.e. excluding unidentifiable ones) whilst sample-based curves represent the number of taxa as a function of the number of sampling units, here defined as the number of auger cores. The minimal sampling effort is 
determined as the minimal number of charcoal fragments or auger cores required to reach the asymptote, which corresponds to the predicted diversity. Securely identified taxa were merged with their 'cf.' analogous before building the curves (e.g. 'taxon A' was merged with 'cf. taxon A').

Finally, we computed the number of taxa recovered exclusively by each sampling method in these sites to assess the complementarity of the methods.

These analyses and the following were performed with R software version 3.5.0 (R Core Team 2018).

\section{Results}

Charcoal richness is positively correlated with taxonomic diversity (Spearman test: rho $=0.8303 ; p$ value $=0.0056$ ). The number of charcoals and identifiable taxa retrieved from each site using each sampling methods is given in Supplementary Information (Tables A.1 and A.2).

\subsection{Effect of sampling method on charcoal concentration}

Due to high variability in charcoal concentration between sites, the results are hereafter given as median \pm standard error. We found no difference in charcoal concentration between auger cores and pits: $2 \pm 1$ vs. $2.7 \pm 1.52$ charcoals/L (Fig. 2 ; Wilcoxon test: $p$-value $=0.6461$ ).

\subsection{Effect of sampling depth}

We found no significant differences in charcoal concentrations between sampling depths when considering the two sampling methods together (Fig. 3A and and Table A.4, Kruskal-Wallis test: $\mathrm{p}$ value $=0.1029$ ), or separately (Fig. 3B-C and Table A.4, Friedman test: $p$-values $=0.7716$ for the pits and 0.2095 for the augers). Nevertheless, the level " $10-20 \mathrm{~cm}$ " tends to be richer in charcoals fragments than the other levels with a higher median, whatever the sampling method under consideration.

\subsection{Effect of site}

When the results of pit and auger methods are pooled, only sites 2 and 8 appear significantly different, the former having a higher charcoal concentration than the latter (Fig. 4A and Table A.3; Kruskal-Wallis test: $p$-value $=0.0096)$. We found a difference between sites 2 and 7 when we compared pits only, and between site 8 and sites 2 and 3 when we compared augers only (Fig. 4B-C and Table A.3; Friedman test: $p$-values $=0.0247$ and 0.0016 , respectively). There are no other remarkable differences.

\subsection{Estimating the minimal sampling effort using rarefaction curves}

Observed and predicted diversity, and sampling effort required to reach the predicted diversity for the richest sites 1, 2, 3 and 9 are summarized in Table 3. Individual- and sample-based rarefaction curves are presented in Fig. 5 . The percentage of the total number of taxa exclusively recovered by each sampling method is presented in Fig. 6 .

Table 3: outputs from individual- and sample-based rarefaction curves in each site, for each of the three sampling methods and when pooled ('All'). 'Exc. soil' refers to the excavated soil investigated for charcoals with the naked eye. 


\begin{tabular}{|c|c|c|c|c|c|c|c|c|c|c|c|}
\hline & & Individu & -based & & & & Sample- & ased & & & \\
\hline $\begin{array}{l}\text { Sit } \\
\text { e }\end{array}$ & $\begin{array}{l}\text { Meth } \\
\text { od }\end{array}$ & $\begin{array}{l}\text { Observ } \\
\text { ed } \\
\text { diversit } \\
y\end{array}$ & $\begin{array}{l}\text { Estimat } \\
\text { ed } \\
\text { asympto } \\
\text { te }\end{array}$ & s. e. & $\begin{array}{l}\text { Predict } \\
\text { ed } \\
\text { diversit } \\
y\end{array}$ & $\begin{array}{l}\text { Sampling } \\
\text { effort } \\
\text { (nb of } \\
\text { charcoal } \\
\text { s)* }\end{array}$ & $\begin{array}{l}\text { Observ } \\
\text { ed } \\
\text { diversit } \\
y\end{array}$ & $\begin{array}{l}\text { Estimat } \\
\text { ed } \\
\text { asympto } \\
\text { te }\end{array}$ & s. e. & $\begin{array}{l}\text { Predict } \\
\text { ed } \\
\text { diversit } \\
y\end{array}$ & $\begin{array}{l}\text { Sampli } \\
\text { ng } \\
\text { effort } \\
\text { (nb of } \\
\text { auger } \\
\text { cores)* }\end{array}$ \\
\hline 1 & $\begin{array}{l}\text { Exc. } \\
\text { soil }\end{array}$ & 17 & 41.615 & 23.873 & 41 & 657 & - & - & - & - & - \\
\hline & Pit & 26 & 36.062 & 8.965 & 36 & 1073 & - & - & - & - & - \\
\hline & $\begin{array}{l}\text { Auger } \\
\mathrm{s}\end{array}$ & 13 & 17.327 & 4.636 & 17 & 76 & 13 & 18.819 & $\begin{array}{l}5.79 \\
9 \\
\end{array}$ & 18 & 54 \\
\hline & All & 39 & 52.944 & 9.863 & 52 & 926 & - & - & - & - & - \\
\hline 2 & $\begin{array}{l}\text { Exc. } \\
\text { soil }\end{array}$ & 5 & 5.992 & 2.183 & 5 & 131 & - & - & - & - & - \\
\hline & Pit & 10 & 30.942 & 17.198 & 30 & 3733 & . & & $=$ & 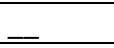 & \\
\hline & $\begin{array}{l}\text { Auger } \\
\mathrm{s}\end{array}$ & 16 & 40.173 & 30.699 & 40 & 1356 & 16 & 50.615 & $\begin{array}{l}32.1 \\
42 \\
\end{array}$ & 50 & 331 \\
\hline & All & 26 & 123.828 & $\begin{array}{l}111.36 \\
66\end{array}$ & 123 & 19544 & - & - & - & - & - \\
\hline 3 & $\begin{array}{l}\text { Exc. } \\
\text { soil }\end{array}$ & 10 & 12.213 & 3.345 & 12 & 165 & - & - & - & - & - \\
\hline & Pit & 20 & 30.057 & 8.961 & 30 & 1017 & & & & & \\
\hline & $\begin{array}{l}\text { Auger } \\
\mathrm{s}\end{array}$ & 14 & 18.127 & 4.840 & 18 & 409 & 14 & 37.438 & $\begin{array}{l}22.7 \\
56 \\
\end{array}$ & 37 & 168 \\
\hline & All & 30 & 38.615 & 6.798 & 38 & 968 & $=$ & $=$ & - & $=$ & $=$ \\
\hline 9 & $\begin{array}{l}\text { Moun } \\
\text { ds }\end{array}$ & 8 & 11.765 & 5.002 & 11 & 44 & 8 & - & - & - & - \\
\hline & Pit & 25 & 55.055 & 28.464 & 55 & 2826 & $=$ & $=$ & $=$ & $=$ & $=$ \\
\hline & $\begin{array}{l}\text { Auger } \\
\mathrm{s}\end{array}$ & 14 & 21.875 & 7.999 & 21 & 99 & 14 & 25.765 & $\begin{array}{l}10.0 \\
86 \\
\end{array}$ & 25 & 74 \\
\hline & All & 43 & 68.657 & 16.071 & 68 & 1192 & - & - & - & - & \\
\hline
\end{tabular}

*based on the integer part of the estimated asymptote, i.e. the predicted diversity.

191 Overall, the pit method tends to recover more taxa (81) than the auger method (57). The excavated soil/mound method (thereafter exc. soil/mound method) recovered less taxa (42), but with a higher variability among sites.

At sites 1,3 and 9 augers presented a lower observed diversity than pits ( 13 vs 26,14 vs 20 and 14 vs 25 , respectively). Only at site 2 did the augers have a greater observed diversity than the pit (16 vs 10).

At sites 2, 3 and 9, the exc. soil/mound method showed a lower observed diversity $(5,10$ and 8 , respectively) than other methods. At site 1 , the observed diversity from excavated soil was lower than in the pit (17 vs 26 ) but higher than in augers (17 vs 13 ).

The sampling effort estimated to reach a plateau varied greatly depending on site and sampling method. We only reached a plateau with the excavated soil from site 2 with a very low diversity of 5 taxa for a sampling effort of 131 charcoals. The estimated sampling effort varied from 1017 to 3733 charcoals with the pit method, from 76 to 1356 charcoals with the auger method and from 44 to 657 with the exc. soil/mound method.

Even the pooling of all methods, i.e. the use of as many charcoals as possible, did not allow to reach an asymptote.

Sampled-based curves sometimes gave a much higher predicted diversity than individual-based curves: 50 vs 40 for site 2 and 37 vs 18 for site 3 with the auger method. Consequently, this led to a very high estimated sampling effort of 331 auger cores for site 2 and 168 auger cores for site 3 . 
Sampled-based curves of sites 1 and 9 presented a predicted diversity closer to that of individualbased curves: 18 vs 17 for site 1 and 25 vs 21 for site 9 . The estimated sampling effort for these two sites was consequently much lower than for sites 2 and 3 with 54 auger cores for site 1 and 74 auger cores for site 9 .

\subsection{Percentage of taxa found exclusively in one or another method} At each site, between 5 and $15 \%$ of the taxa were only found through the exc. soil/mounds method (Fig. 6 and Table A.5). In sites 1, 3 and 9, 30 to 40\% of the taxa were only found in the pit and 18 to $21 \%$ were only found in the auger cores. Site 2 shows a different pattern with $50 \%$ of the taxa found only in auger cores and $23 \%$ found only in the pit.

\section{Discussion}

The observed diversity was lower with the auger method than with the pit method at three sites out of four. The low number of taxa in most auger cores could explain this difference. Indeed, we noticed during charcoal identification that many auger cores contained either a single charcoal and consequently a single taxon or a majority of charcoals belonging to the same taxon: nearly $34 \%$ of the auger cores containing charcoals were monospecific and $25 \%$ contained only one charcoal fragment. This is probably due to the small soil surface covered by an auger core (ca. 40 to $60 \mathrm{~cm}^{2}$ depending on devices), which increases the probability of sampling a single individual (e.g. a piece of trunk). Therefore, despite a better spatial coverage on a 1 ha area, the fact that we get few taxa in each auger core did not help to have a higher taxonomic richness than with pits. Only the augers from site 2 allowed to recover a better observed diversity. At this site, the pit assemblage was dominated by two taxa counting together for $97 \%$ of all charcoal pieces. In this case, the spatially extended coverage of augers allowed to better catch taxonomic diversity: $50 \%$ of the taxa found at this site were exclusive to augers (Fig. 6). In the other sites, the auger method also allowed to recover new taxa that we had not found in pits. In sites 1, 3 and 9, between 18 and $21 \%$ of the taxa were found exclusively in augers. There is a need for other methodologic studies to compare our results. Indeed, the auger method is rarely used in pedoanthracology (Feiss et al. 2017) and particularly in the tropics where we did not find any studies using this method, except for prospection (Tardy 1998; Hubau et al. 2012; Bourland et al. 2015; Dotte-Sarout and Kahn 2017). The exc. soil/mound method also allowed to discover new taxa that we did not recovered with the two other methods. This opportunistic method is not intended to replace the two others because of the bias induced by a naked eye collect. However, our results show that it can be used additively to obtain a supplementary qualitative information. The variability of the observed diversity obtained with this method depends on the presence of monospecific lenses. At site 2 , we reached an asymptote because of a high amount of charcoal fragments from the same individual (probably a piece of trunk or branch which was broken during digging). At site 9, we obtained a lower observed diversity than with the excavated soils from site 1 and 3 despite a better spatial coverage ( 7 sampled mounds) because of the overrepresentation of some taxa.

These results suggest that these three methods are complementary for the recovery of charcoal $>4$ $\mathrm{mm}$. With the pit method, which is a very local sampling point, there is a risk to dig at the location of a monospecific lens of charcoal which can correspond to a single individual (cf. site 2). A similar issue has been pointed by Scheel-Ybert et al (2003), in a site at the ecotone between cerrado and semideciduous forest in Brazil. In trenches of $1.0 \mathrm{~m} \times 2.0 \mathrm{~m}$ large and up to $2.4 \mathrm{~m}$ depth, a maximum of 15 taxa were identified. One can be surprised by such poor taxonomic diversity in a highly diverse floristic environment, but the authors point out that trees burn were they stand, especially during a natural fire, explaining the feeble amount of taxa discovered in a single sampling point. This could 
explain what we observed at site 2 . In this case, a broader spatial sampling is required to overcome the overrepresentation issue. Even if auger cores are often monospecific and contain few charcoals, almost every new core brings in a new taxon. At site 1,54\% of the taxa recovered in augers cores were found only once (i.e. in only one core) and this figure reaches $75 \%$ at site 2 and $71 \%$ at sites 3 and 9 . At sites 2 and 3 , characterized by many rare taxa, this resulted in a high predicted diversity and a high estimated sampling effort (sample-based curves) because each new auger core is likely to contain a new taxon. Collecting charcoals on mounds can also allow to increase the taxonomic diversity of a charcoal assemblage of a site (see Tardy 1998), but one has to be careful not to pick only the largest charcoal fragments which can come from the same burnt individual.

\subsection{Obtain a representative assemblage in a species-rich area}

The minimal sampling effort estimated from our data is very high, exceeding 1000 charcoals with the pit method to reach 30 taxa (site 3 ) and even 3000 when there is an overrepresentation of some taxa in the charcoal assemblage (site 2). With the auger method, 76 to more than 1300 charcoal pieces and 54 to more than 300 auger cores would be required to reach a hypothetic plateau of 17 to 30 taxa, depending on taxonomic richness and monospecific concentrations of charcoals. In a temperate environment, where the floristic diversity is weaker, Feiss et al. (2017) estimated the minimal sampling effort to 500 charcoals with the pit method and to 600 charcoals with the auger method. If these figures can be achieved in temperate milieus, most of our estimated minimal sampling efforts are however not realistic both in terms of number of charcoals and number of auger cores, because of the time required to drill and sieve large amounts of soil. Even when considering the three methods together, which can be considered as a greater sampling effort because it multiplies the number of charcoals, the curves did not reach an asymptote (Fig. 5). As a matter of fact, constantly increasing the sampling effort would lead to the collection of more and more taxa and would only push back the hypothetical asymptote (predicted diversity).

With an estimated tree diversity of 1,700 native species in French Guiana (Molino et al. 2009), it seems unrealistic to try to get a stabilization of the rarefaction curves, whatever the sampling method under consideration. The sampling effort should simply aim to maximize the number of charcoals collected, which should in turn mechanically maximize taxonomic diversity. This can be achieved by combining pit and auger sampling methods, thereby overcoming their respective biases (monospecific auger cores, spatially limited pits). Now, if it is not possible to estimate a minimum sampling effort based on the extrapolation of rarefaction curves, then how to proceed?

The incapacity to reach a plateau with anthracologic data has already been observed in Brazilian coastal environments (Scheel-Ybert 2002) and in tropical forests of New Caledonia (Dotte-Sarout et al. 2015). In these cases, the construction of a Gini-Lorenz curve, which represents the cumulative frequencies of taxa as a function of the relative taxa rank, is an alternative to assess the representativeness of an anthracological assemblage (Chabal et al. 1999; Scheel-Ybert 2002). The intersection between the curve and the second diagonal gives the Gini-Lorenz index which is typically comprised between 28:72 and 22:78 in tropical environments (estimations based on floristic surveys, Scheel-Ybert 2002). An index of 22:78 means that $22 \%$ of the taxa are represented in $78 \%$ of the sampled individuals. When the Gini-Lorenz index of an anthracological assemblage falls within this range, this assemblage can be considered as representative of the past floristic diversity, even if no conclusive plateau was reached with rarefaction or accumulation curves. Therefore, the Gini-Lorenz index may be a good way to assess the representativeness of anthracological assemblages from French Guianan forests as well, and the minimal sampling effort may be estimated as the one required to obtain typical tropical values of the Gini-Lorenz index. According to Scheel-Ybert (2002), 
this minimal sampling effort would be of 200-300 charcoal fragments per sampling level in a pit or a trench.

\subsection{Proposal for an efficient sampling scheme}

How can the sampling protocol be optimized to get the best taxonomic diversity? According to our results, the charcoal concentration is equivalent between the pit and the auger sampling methods for a same volume of sampled soil (Wilcoxon test). Therefore, both are equally efficient for the recovery of soil charcoals. Nevertheless, our results also show that the two methods should be used together to overcome their respective bias and to get the best picture of the past diversity on a study site.

The number of pits or auger cores can be adjusted according to the charcoal richness of a site. Among the 6 sites compared on the basis of their charcoal concentration, whatever the sampling method we saw that some are significantly richer. In these sites, it is worthy to increase the sampling effort to get high diversity assemblages, but in the poorest sites, the effort should be adapted to not lose too much time digging for feeble amounts of charcoals. It is very helpful to have an idea of the charcoal richness of a site before starting systematic digging methods, bearing in mind that, according to our experience in the Nouragues forest, drilling 20 auger cores of $60 \mathrm{~cm}$-depth in a 1-ha area takes about 10 hours, whereas digging and sampling an $80 \times 80$ pit of the same depth takes $c a .4$ hours with two people. To quickly assess the charcoal richness of a site before starting any excavation, prospections can be made thanks to small test-pits (Morin-Rivat et al. 2016), auger cores (Hubau et al. 2012; Kahn et al. 2015; Feiss et al. 2017) and investigation of uprooted tree mounds (Tardy 1998) if they are abundant in the site of interest. In French Guiana, Riéra et al. (1989) estimated the windfall frequency at $0.75 / \mathrm{ha} / \mathrm{yr}, 33 \%$ of which accounting for uprooted trees. In oldgrowth temperate forests of Czech Republic, for example, the uprooting frequency vary from 0.6 (highlands) to 1.9 (mountains) (Šamonil et al. 2017). Investigation of uprooted tree mounds is the fastest method to have a glimpse on charcoal distribution: we estimated that about 3 hours are needed to prospect about ten uprooted mounds in a 1-ha area.

We found no statistical evidence to differentiate charcoal richness between sampling levels, but this might be due to a low number of replicates. However, our results show that the soil layer between 10 and $20 \mathrm{~cm}$-depth tends to be the richest one. Our charcoal assemblages were dated to the late Holocene (Bodin et al. 2020); in other charcoal studies, the highest charcoal concentration concerning Holocene-dated fragments is often observed in the first $50 \mathrm{~cm}$. Peaks were recorded between 0 and $40 \mathrm{~cm}$ depth in temperate zones (Carcaillet 2001; Touflan et al. 2010; Robin et al. 2013; Feiss et al. 2017) and between 0 and $50 \mathrm{~cm}$ depth in tropical ones (Piperno and Becker 1996; Hubau et al. 2013; Fernandes Caromano et al. 2013; Vleminckx et al. 2014). Variations may depend on the type of soil and on the intensity of soil disturbances or bioturbation. The activity of the pedofauna plays a key role in the accumulation of charcoal and organic matter in the first layers of the soil. In the tropics, termites, ants and earthworms mix old and recent organic matter in soil and contribute to the upward reworking of the buried material (Lee and Wood 1971; Lavelle 1997; Gabet et al. 2003; Topoliantz et al. 2006) which can explain the concentration of charcoal in the upper soil layers. Burrows of larger animals, tree uprooting and tree root activity are also important processes in the mixing of organic matter in soil (Lavelle et al. 1997; Šamonil et al. 2015). To assess the burial depth of charcoal fragments, a quick prospection with auger cores can be done before a systematic sampling. In our case, focusing on these charcoal-rich levels during sampling and not digging too deep would have saved time to make some additional auger cores at the most interesting sampling depths. In our case, most of the information given by anthracological data on past human activity was contained in the first $30 \mathrm{~cm}$ of soil (Bodin et al. 2020). Therefore, selecting richest depths for sampling can be enough informative. 
Depending on the time available for fieldwork and site accessibility, a sampling scheme could be to dig 3 to 5 pits in a site. One pit can be large enough to allow pedological description (e.g. $80 \times 80 \mathrm{~cm}$ ) and the others can be smaller (e.g. $30 \times 30 \mathrm{~cm}$ ). Multiplying the number of pits would allow to overcome spatial heterogeneity issues, as several studies have shown that charcoals deposit heterogeneously in tropical (Vleminckx et al. 2014; Morin-Rivat et al. 2016), boreal (Ohlson and Tryterud 2000) and temperate environments (Eckmeier et al. 2007; Touflan and Talon 2009). If logistical limitations prevent the digging of several pits, then each profile of a same pit can be searched for charcoals to increase the number of samples. Then the sampling can be supplemented by auger cores on a grid superimposed on pits, the spatial coverage of which may depend on the size of the site and its topography, or could be adapted to match that of an existing floristic survey (generally 1 ha for tree inventory plots). As recommended by Feiss et al. (2017) in temperate forests, the auger cores should be sufficiently spaced, i.e. a few meters, to avoid spatial autocorrelation. The number of auger cores can be adapted to vegetation constraints and accessibility (especially in tropical forests). It may also be adjusted according to the volume of soil collected from pits for comparison purposes, as both methods are equally efficient for charcoal recovery.

Our study showed that the two digging methods that we compared - pit and auger sampling - each have their biases, so it can be problematic to choose only one, at least in highly diverse tropical environments. Digging a single pit can be risky, because it may contain an assemblage in which a few taxa are over-represented, an issue than can only be detected after the identification phase in the lab. However, we found that auger cores contained fewer taxa than pits despite a higher sampling coverage, as many cores were monospecific. Nevertheless, our results showed that the two methods are complementary because they allowed to collect different taxa. We therefore suggest combining the two methods to get as diverse anthracological assemblages as possible, by digging several pits to overcome spatial heterogeneity issues and by drilling cores to get a better representativeness of the taxonomic diversity in the tropical forest. The opportunistic harvesting of charcoals during digging or on uprooted tree mounds can also be used to increase the pool of taxa in the anthracological record. This is also a very quick method to get an insight into the charcoal richness of a site, which can be helpful to adjust the sampling effort with the two digging methods.

\section{Acknowledgments}

This study is part of the LongTIme project (Long Term Impact of ancient Amerindian settlements on Guianese forests). We acknowledge an Investissement d'Avenir grant from the Agence Nationale de la Recherche (CEBA: ANR-10-LABX-25-01). We are grateful to all the people who helped during the three fieldwork campaigns: C. Docquier, F. Jeanne, G. Odonne, J.-L. Smock, M.-A. Tareau, M. Rapinski, M. Ayanne, M. Roy and T. Leblanc. We also thank L. Paradis for the realization of Fig. 1 and B. Flotterer, C. Favier, G. le Moguédec and V. Bonhomme for their helpful advices on the analyses conducted in this paper.

\section{References}

Bachelet C, Scheel-Ybert R (2017) Landscape and firewood selection in the Santa Elina rock shelter (Mato Grosso, Brazil) during the Holocene. Quat Int 431:52-60 . https://doi.org/10.1016/j.quaint.2015.12.019

Badal Garcia E (1992) L'anthracologie préhistorique : à propos de certains problèmes méthodologiques. Bull Société Bot Fr Actual Bot 139:167-189 
Bodin SC, Molino J-F, Odonne G, Bremond L (2020) Unraveling pre-Columbian occupation patterns in the tropical forests of French Guiana using an anthracological approach. Veg Hist Archaeobotany 29:567-580 . https://doi.org/10.1007/s00334-019-00767-w

Bodin SC, Scheel-Ybert R, Beauchêne J, Molino J-F, Bremond L (2019) CharKey: An electronic identification key for wood charcoals of French Guiana. IAWA J 40:75-91

Bourland N, Cerisier F, Daïnou K, Smith AL, Hubau W, Beeckman H, Brostaux Y, Fayolle A, Biwolé AB, Fétéké F, Gillet J-F, Morin-Rivat J, Lejeune P, Tiba EN, Van Acker J, Doucet J-L (2015) How Tightly Linked Are Pericopsis elata (Fabaceae) Patches to Anthropogenic Disturbances in Southeastern Cameroon? Forests 6:293-310 . https://doi.org/10.3390/f6020293

Carcaillet C (2001) Are Holocene wood-charcoal fragments stratified in alpine and subalpine soils? Evidence from the Alps based on AMS 14C dates. The Holocene 11:231-242. https://doi.org/10.1191/095968301674071040

Carcaillet C, Thinon M (1996) Pedoanthracological contribution to the study of the evolution of the upper treeline in the Maurienne Valley (North French Alps): methodology and preliminary data. Rev Palaeobot Palynol 91:399-416

Chabal L (1997) Forêts et sociétés en Languedoc (Néolithique final, Antiquité tardive). L'anthracologie, méthode et paléoécologie, Editions de la Maison des Sciences de l'Homme. Editions de la Maison des Sciences de l'Homme, Paris

Chabal L, Fabre L, Terral JF, Théry-Parisot I (1999) L'anthracologie. In: Bourquin-Mignot C, Brochier J, Chabal L, Crozat S, Fabre L, Guibal F, Marinval P, Richard H, Terral JF, Théry-Parisot I (eds) La botanique. Errance, Paris, pp 43-104

Chao A, Gotelli NJ, Hsieh TC, Sander EL, Ma KH, Colwell RK, Ellison AM (2014) Rarefaction and extrapolation with Hill numbers: a framework for sampling and estimation in species diversity studies. Ecol Monogr 84:45-67 . https://doi.org/10.1890/13-0133.1

Chrzazvez J, Théry-Parisot I, Fiorucci G, Terral J-F, Thibaut B (2014) Impact of post-depositional processes on charcoal fragmentation and archaeobotanical implications: experimental approach combining charcoal analysis and biomechanics. J Archaeol Sci 44:30-42 . https://doi.org/10.1016/j.jas.2014.01.006

Détienne P, Jacquet P (1983) Atlas d'identification des bois de l'Amazonie et des régions voisines. Centre Technique Forestier Tropical, Nogent-Sur-Marne

Détienne $P$, Jacquet $P$, Mariaux A (1982) Manuel d'identification des bois tropicaux. Tome 3 : Guyane française. Centre Technique Forestier Tropical, Nogent-Sur-Marne

Di Pasquale G, Marziano M, Impagliazzo S, Lubritto C, De Natale A, Bader MY (2008) The Holocene treeline in the northern Andes (Ecuador): first evidence from soil charcoal. Palaeogeogr Palaeoclimatol Palaeoecol 259:17-34

Dotte-Sarout E (2017) Evidence of forest management and arboriculture from wood charcoal data: an anthracological case study from two New Caledonia Kanak pre-colonial sites. Veg Hist Archaeobotany 26:195-211 
Dotte-Sarout E, Carah X, Byrne C (2015) Not just carbon: assessment and prospects for the application of anthracology in Oceania: Not just carbon. Archaeol Ocean 50:1-22 . https://doi.org/10.1002/arco.5041

Dotte-Sarout E, Kahn JG (2017) Ancient woodlands of Polynesia: A pilot anthracological study on Maupiti Island, French Polynesia. Quat Int 457:6-28 . https://doi.org/10.1016/j.quaint.2016.10.032

Dutoit T, Thinon M, Talon B, Buisson E, Alard D (2009) Sampling soil wood charcoals at a high spatial resolution: a new methodology to investigate the origin of grassland plant communities: Sampling soil wood charcoals at a high spatial resolution. J Veg Sci 20:349-358 . https://doi.org/10.1111/j.1654-1103.2009.05403.x

Eckmeier E, Rösch M, Ehrmann O, Schmidt MWI, Schier W, Gerlach R (2007) Conversion of biomass to charcoal and the carbon mass balance from a slash-and-burn experiment in a temperate deciduous forest. The Holocene 17:539-542 . https://doi.org/10.1177/0959683607077041

Eisinga R, Heskes T, Pelzer B, Te Grotenhuis M (2017) Exact p-values for pairwise comparison of Friedman rank sums, with application to comparing classifiers. BMC Bioinformatics 18:68 . https://doi.org/10.1186/s12859-017-1486-2

Feiss T, Horen H, Brasseur B, Lenoir J, Buridant J, Decocq G (2017) Optimal sampling design and minimal effort for soil charcoal analyses considering the soil type and forest history. Veg Hist Archaeobotany 26:627-637

Fernandes Caromano C, Cascon LM, Neves EG, Scheel-Ybert R (2013) Revealing Fires and Rich Diets: Macro- and Micro-archaeobotanical Analysis at the Hatahara Site, Central Amazonia. Tipití J Soc Anthropol Lowl S Am 11:40-51

Gabet EJ, Reichman OJ, Seabloom EW (2003) The Effects of Bioturbation on Soil Processes and Sediment Transport. Annu Rev Earth Planet Sci 31:249-273. https://doi.org/10.1146/annurev.earth.31.100901.141314

Heinz C, Thiébault S (1998) Characterization and Palaeoecological Significance of Archaeological Charcoal Assemblages during Late and Post-Glacial Phases in Southern France. Quat Res 50:56-68 . https://doi.org/10.1006/qres.1998.1978

Hsieh TC, Ma KH, Chao A (2016) iNEXT: an R package for rarefaction and extrapolation of species diversity (Hill numbers). Methods Ecol Evol 7:1451-1456 . https://doi.org/10.1111/2041210X.12613

Hubau W, Van den Bulcke J, Kitin P, Mees F, Baert G, Verschuren D, Nsenga L, Van Acker J, Beeckman $H$ (2013) Ancient charcoal as a natural archive for paleofire regime and vegetation change in the Mayumbe, Democratic Republic of the Congo. Quat Res 80:326-340

Hubau W, Van den Bulcke J, Kitin P, Mees F, Van Acker J, Beeckman H (2012) Charcoal identification in species-rich biomes: A protocol for Central Africa optimised for the Mayumbe forest. Rev Palaeobot Palynol 171:164-178

Kahn JG, Dotte-Sarout E, Molle G, Conte E (2015) Mid- to Late Prehistoric Landscape Change, Settlement Histories, and Agricultural Practices on Maupiti, Society Islands (Central Eastern Polynesia). J Isl Coast Archaeol 10:363-391 . https://doi.org/10.1080/15564894.2014.1001922 
Lavelle P (1997) Faunal Activities and Soil Processes: Adaptive Strategies That Determine Ecosystem Function. In: Advances in ecological research. Academic Press, pp 93-132

Lavelle P, Bignell D, Lepage M, Wolters V, Roger P-A, Ineson P, Heal OW, Dhillion S (1997) Soil function in a changing world: the role of invertebrate ecosystem engineers. Eur J Soil Biol 33:159-193

Lee KE, Wood TG (1971) Termites and soils. Academic Press, London, UK

Molino JF, Sabatier D, Prévost MF, Frame D, Gonzalez S, Bilot-Guérin V (2009) Etablissement d'une liste des especes d'arbres de la Guyane française. IRD Cayenne

Morin-Rivat J, Biwolé A, Gorel A-P, Vleminckx J, Gillet J-F, Bourland N, Hardy OJ, Smith AL, Daïnou K, Dedry L, Beeckman H, Doucet J-L (2016) High spatial resolution of late-Holocene human activities in the moist forests of central Africa using soil charcoal and charred botanical remains. The Holocene 26:1954-1967 . https://doi.org/10.1177/0959683616646184

Morin-Rivat J, Fayolle A, Gillet J-F, Bourland N, Gourlet-Fleury S, Oslisly R, Bremond L, Bentaleb I, Beeckman H, Doucet J-L (2014) New Evidence of Human Activities During the Holocene in the Lowland Forests of the Northern Congo Basin. Radiocarbon 56:209-220 . https://doi.org/10.2458/56.16485

Nelle O, Robin V, Talon B (2013) Pedoanthracology: Analysing soil charcoal to study Holocene palaeoenvironments. Quat Int 289:1-4 . https://doi.org/10.1016/j.quaint.2012.11.024

Ohlson M, Tryterud E (2000) Interpretation of the charcoal record in forest soils: forest fires and their production and deposition of macroscopic charcoal. The Holocene 10:519-525

Piperno DR, Becker P (1996) Vegetational History of a Site in the Central Amazon Basin Derived from Phytolith and Charcoal Records from Natural Soils. Quat Res 45:202-209. https://doi.org/10.1006/qres.1996.0020

Pohlert T (2020) PMCMRplus: Calculate Pairwise Multiple Comparisons of Mean Rank Sums Extended

R Core Team (2018) R: A language and environment for statistical computing. R Foundation for Statistical Computing, Vienna, Austria

Riéra B, Puig H, Lescure JP (1989) La dynamique de la forêt naturelle. Bois For Trop 219:69-78

Robin V, Talon B, Nelle O (2013) Pedoanthracological contribution to forest naturalness assessment. Quat Int 289:5-15 . https://doi.org/10.1016/j.quaint.2012.02.023

Šamonil P, Daněk P, Adam D, Phillips JD (2017) Breakage or uprooting: How tree death type affects hillslope processes in old-growth temperate forests. Geomorphology 299:76-84 . https://doi.org/10.1016/j.geomorph.2017.09.023

Šamonil P, Daněk P, Schaetzl RJ, Vašíčková I, Valtera M (2015) Soil mixing and genesis as affected by tree uprooting in three temperate forests. Eur J Soil Sci 66:589-603 . https://doi.org/10.1111/ejss.12245

Scheel-Ybert R (2002) Evaluation of sample reliability in extant and fossil assemblages. Bar Int Ser 1063:9-16 
Scheel-Ybert R (2001) Man and Vegetation in Southeastern Brazil during the Late Holocene. J Archaeol Sci 28:471-480 . https://doi.org/10.1006/jasc.2000.0577

Scheel-Ybert R (2016) Charcoal collections of the world. IAWA J 37:489-505

Scheel-Ybert R, Gonçalves TAP (2017) Primeiro Atlas Antracológico de Espécies Brasileiras/First Anthracological Atlas of Brazilian Species. Museu Nacional, Rio de Janeiro

Scheel-Ybert R, Gouveia SEM, Pessenda LCR, Aravena R, Coutinho LM, Boulet R (2003) Holocene palaeoenvironmental evolution in the São Paulo State (Brazil), based on anthracology and soil $\delta 13 C$ analysis. The Holocene 13:73-81 . https://doi.org/10.1191/0959683603hl596rp

Talon B (2010) Reconstruction of Holocene high-altitude vegetation cover in the French southern Alps: evidence from soil charcoal. The Holocene 20:35-44

Tardy C (1998) Paléoincendies naturels, feux anthropiques et environnements forestiers de Guyane Française du tardiglaciaire à l'holocène récent : Approches chronologique et anthracologique. PhD dissertation, Université Montpellier 2

Théry-Parisot I, Chabal L, Chrzavzez J (2010) Anthracology and taphonomy, from wood gathering to charcoal analysis. A review of the taphonomic processes modifying charcoal assemblages, in archaeological contexts. Palaeogeogr Palaeoclimatol Palaeoecol 291:142-153 . https://doi.org/10.1016/j.palaeo.2009.09.016

Thinon M (1978) pedoanthracologie: une nouvelle methode d'analyse phytochronologique depuis le neolithique. Comptes Rendus Hebd Seances Ser Sci Nat

Topoliantz S, Ponge J-F, Lavelle P (2006) Humus components and biogenic structures under tropical slash-and-burn agriculture. Eur J Soil Sci 57:269-278 . https://doi.org/10.1111/j.13652389.2005.00736.x

Touflan P, Talon B (2009) Spatial reliability of soil charcoal analysis: The case of subalpine forest soils. Écoscience 16:23-27 . https://doi.org/10.2980/16-1-3177

Touflan P, Talon B, Walsh K (2010) Soil charcoal analysis: a reliable tool for spatially precise studies of past forest dynamics: a case study in the French southern Alps. The Holocene 20:45-52 . https://doi.org/10.1177/0959683609348900

Vleminckx J, Morin-Rivat J, Biwolé AB, Daïnou K, Gillet J-F, Doucet J-L, Drouet T, Hardy OJ (2014) Soil Charcoal to Assess the Impacts of Past Human Disturbances on Tropical Forests. PLoS ONE 9:e108121 . https://doi.org/10.1371/journal.pone.0108121

Wheeler EA (2011) InsideWood - a web resource for hardwood anatomy. IAWA J 32:199-211

\section{Supplementary material}

Table A.1: charcoal concentration and number of identifiable taxa recovered in each site investigated with the pit and the auger sampling methods, with respect to the sampling depths and to the volume of soil sampled 


\begin{tabular}{|c|c|c|c|c|c|c|c|}
\hline $\begin{array}{l}\mathrm{Si} \\
\text { te }\end{array}$ & $\begin{array}{l}\text { Depth } \\
(\mathrm{cm})\end{array}$ & $\begin{array}{l}\text { Vol. } \\
\text { (L) }\end{array}$ & $\begin{array}{l}\text { Charcoal } \\
\text { concentration } \\
\left(\mathrm{nb}_{\text {tot }} / \mathrm{L}\right)\end{array}$ & $\begin{array}{l}\mathrm{Nb} \text { of } \\
\text { identifiable } \\
\text { taxa }\end{array}$ & $\begin{array}{l}\text { Vol. } \\
\text { (L) }\end{array}$ & $\begin{array}{l}\text { Charcoal } \\
\text { concentration } \\
\left(\mathrm{nb}_{\text {tot }} / \mathrm{L}\right)\end{array}$ & $\begin{array}{l}\mathrm{Nb} \text { of } \\
\text { identifiable } \\
\text { taxa }\end{array}$ \\
\hline \multirow{6}{*}{$\stackrel{\vec{D}}{\frac{D}{n}}$} & 10 & 10 & 2,8 & 10 & 4,2 & 1,67 & 2 \\
\hline & 20 & 10 & 12,8 & 22 & 4,2 & 2,62 & 6 \\
\hline & 30 & 10 & 1,3 & 9 & 4,05 & 0,99 & 4 \\
\hline & 40 & 10 & 0,6 & 5 & 3,9 & 0,51 & 1 \\
\hline & 50 & 10 & 1,1 & 4 & 2,85 & 0,35 & 0 \\
\hline & 60 & 10 & 0,4 & 2 & 1,65 & 4,85 & 4 \\
\hline \multirow{6}{*}{. } & 10 & 10 & 26,2 & 3 & 5,1 & 2,94 & 3 \\
\hline & 20 & 10 & 5,1 & 8 & 5,1 & 5,69 & 7 \\
\hline & 30 & 10 & 8 & 2 & 5,1 & 2,75 & 5 \\
\hline & 40 & - & - & - & 4,95 & 4,44 & 7 \\
\hline & 50 & - & - & - & 2,85 & 3,51 & 5 \\
\hline & 60 & - & - & - & 0,6 & 8,33 & 1 \\
\hline \multirow{6}{*}{$\stackrel{m}{\stackrel{n}{n}}$} & 10 & 10 & 0,6 & 4 & 3,75 & 1,87 & 1 \\
\hline & 20 & 10 & 6,3 & 12 & 3,75 & 16,27 & 4 \\
\hline & 30 & 10 & 7,3 & 10 & 3,75 & 2,13 & 4 \\
\hline & 40 & 10 & 2,4 & 4 & 3,75 & 2,67 & 5 \\
\hline & 50 & 10 & 0,3 & 3 & 3,45 & 1,74 & 4 \\
\hline & 60 & - & - & - & 3,45 & 2,03 & 2 \\
\hline \multirow{6}{*}{$\begin{array}{l}\stackrel{\bullet}{ \pm} \\
\stackrel{ \pm}{n}\end{array}$} & 10 & 10 & 0 & 0 & 4,95 & 0,81 & 2 \\
\hline & 20 & 10 & 0,6 & 3 & 4,95 & 11,92 & 6 \\
\hline & 30 & 10 & 0,5 & 3 & 4,95 & 1,41 & 2 \\
\hline & 40 & 10 & 0 & 0 & 4,05 & 0 & 0 \\
\hline & 50 & 10 & 0 & 0 & 3,75 & 0,8 & 1 \\
\hline & 60 & - & - & - & 1,5 & 1,33 & 1 \\
\hline \multirow{5}{*}{ 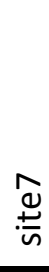 } & 10 & 10 & 0 & 0 & - & - & - \\
\hline & 20 & 10 & 0 & 0 & - & - & - \\
\hline & 30 & 10 & 0,3 & 3 & - & - & - \\
\hline & 40 & 10 & 0 & 0 & - & - & - \\
\hline & 50 & 10 & 0,4 & 2 & - & - & - \\
\hline \multirow{6}{*}{$\begin{array}{l}\stackrel{\infty}{ \pm} \\
\stackrel{ \pm}{\omega}\end{array}$} & 10 & 10 & 0,5 & 3 & 0,9 & 1,11 & 1 \\
\hline & 20 & 10 & 2,6 & 7 & 0,9 & 0 & 0 \\
\hline & 30 & 10 & 0 & 0 & 0,9 & 0 & 0 \\
\hline & 40 & 10 & 0,1 & 1 & 0,9 & 0 & 0 \\
\hline & 50 & - & - & - & 0,9 & 0 & 0 \\
\hline & 60 & - & - & - & 0,75 & 0 & 0 \\
\hline \multirow{6}{*}{$\begin{array}{l}\frac{9}{4} \\
\frac{+}{n}\end{array}$} & 10 & 10 & 8,9 & 11 & 5,1 & 0,78 & 2 \\
\hline & 20 & 10 & 4 & 12 & 5,1 & 3,14 & 4 \\
\hline & 30 & 10 & 2,4 & 7 & 5,1 & 3,14 & 9 \\
\hline & 40 & 10 & 2,1 & 5 & 5,1 & 0,78 & 2 \\
\hline & 50 & 10 & 1 & 5 & 5,1 & 0,20 & 1 \\
\hline & 60 & 10 & 0,3 & 2 & 4,2 & 0,24 & 0 \\
\hline
\end{tabular}




\begin{tabular}{|c|c|c|c|c|c|c|c|}
\hline & 10 & - & - & - & 4,8 & 1,46 & 1 \\
\hline & 20 & - & - & - & 4,8 & 1,25 & 6 \\
\hline & 30 & - & - & - & 4,8 & 2,08 & 6 \\
\hline & 40 & - & - & - & 4,8 & 2,92 & 3 \\
\hline d. & 50 & - & - & - & 4,8 & 1,67 & 2 \\
\hline 婄 & 60 & - & - & - & 4,8 & 1,04 & 2 \\
\hline
\end{tabular}

Table A.2: number of charcoals and number of identifiable taxa recovered in excavated pit soils and 544 tree uprooting mounds

\begin{tabular}{|l|l|l|l|}
\hline Site & Type of sampled feature & Total nb of charcoals & Nb of identifiable taxa \\
\hline Site 1 & Excavated soil & 67 & 18 \\
\hline Site 2 & Excavated soil & 163 & 5 \\
\hline Site 3 & Excavated soil & 67 & 10 \\
\hline Site 6 & Excavated soil & 7 & 1 \\
\hline Site 7 & Excavated soil & 1 & 1 \\
\hline Site 8 & Excavated soil & 11 & 5 \\
\hline Site 9 & Mounds $(\mathrm{x} 7)$ & 23 & 8 \\
\hline Site 10 & Mounds $(\mathrm{x} 10)$ & 63 & 7 \\
\hline Site 11 & Mounds $(\mathrm{x} 14)$ & 60 & 15 \\
\hline Site 12 & Mounds $(\mathrm{x} 3)$ & 52 & 3 \\
\hline
\end{tabular}

Table A.3: charcoal concentrations (median \pm se) considering the pit and auger sampling methods together and separately. The letters indicate the significant differences according to the Conover post-hoc test for the pit + augers comparison and to the exact all-pairs comparisons test for the pit and augers comparisons $(p<0.05)$

\begin{tabular}{|l|l|l|l|}
\hline Site & $\begin{array}{l}\text { Pit and } \\
\text { augers }\end{array}$ & Pit & Augers \\
\hline 1 & $2.14 \pm$ & $2.80 \pm$ & $1.33 \pm$ \\
& $1.84^{\mathrm{ab}}$ & $3.61^{\mathrm{ab}^{\mathrm{b}}}$ & $0.69^{\mathrm{ab}}$ \\
\hline 2 & $5.39 \pm$ & $8.00 \pm$ & $3.98 \pm$ \\
& $3.64^{\mathrm{a}}$ & $6.60^{\mathrm{a}}$ & $0.87^{\mathrm{a}}$ \\
\hline 3 & $4.22 \pm$ & $6.30 \pm$ & $2.08 \pm$ \\
& $2.37^{\mathrm{ab}}$ & $2.09^{\mathrm{ab}}$ & $2.37^{\mathrm{a}}$ \\
\hline 6 & $0.70 \pm$ & $0.50 \pm$ & $1.07 \pm$ \\
& $1.89^{\mathrm{ab}}$ & $0.19^{\mathrm{ab}}$ & $1.85^{\mathrm{ab}}$ \\
\hline 7 & -- & $0.00 \pm$ & -- \\
& & $0.10^{\mathrm{b}}$ & \\
\hline 8 & $0.25 \pm$ & $0.50 \pm$ & $0.00 \pm$ \\
& $0.42^{\mathrm{b}}$ & $0.80^{\mathrm{ab}}$ & $0.19^{\mathrm{b}}$ \\
\hline 9 & $3.14 \pm$ & $4.00 \pm$ & $0.78 \pm$ \\
& $1.12^{\mathrm{ab}}$ & $1.96^{\mathrm{ab}}$ & $0.57^{\mathrm{ab}}$ \\
\hline 10 & -- & -- & $1.56 \pm$ \\
& & & $0.28^{\mathrm{ab}}$ \\
\hline
\end{tabular}


Table A.4: charcoal concentrations (median \pm se) of sites 1, 2, 3, 6, 8 and 9 in each sampling depth considering the pit and auger sampling methods together and separately

\begin{tabular}{|l|l|l|l|}
\hline $\begin{array}{l}\text { Sampling } \\
\text { depth }(\mathrm{cm})\end{array}$ & Pit and augers & Pit & Augers \\
\hline $0-10$ & $1.39 \pm 2.13$ & $0.60 \pm 3.64$ & $1.46 \pm 0.28$ \\
\hline $10-20$ & $4.55 \pm 1.48$ & $4.00 \pm 1.63$ & $3.14 \pm 2.28$ \\
\hline $20-30$ & $1.77 \pm 0.76$ & $1.30 \pm 1.28$ & $2.08 \pm 0.41$ \\
\hline $30-40$ & -- & -- & $0.78 \pm 0.65$ \\
\hline $40-50$ & -- & -- & $0.80 \pm 0.47$ \\
\hline $50-60$ & -- & -- & $1.33 \pm 1.14$ \\
\hline
\end{tabular}

553

554 Table A.5: number of exclusive taxa recovered with each sampling method for sites 1, 2, 3 and 9

\begin{tabular}{|l|l|l|l|l|}
\hline & Site 1 & Site 2 & Site 3 & Site 9 \\
\hline Exc.soil/mounds & 6 & 3 & 4 & 2 \\
\hline Pit & 12 & 6 & 9 & 18 \\
\hline Augers & 7 & 13 & 6 & 9 \\
\hline Total nb. of taxa & $\mathbf{3 9}$ & $\mathbf{2 6}$ & $\mathbf{3 0}$ & $\mathbf{4 3}$ \\
\hline
\end{tabular}

555 


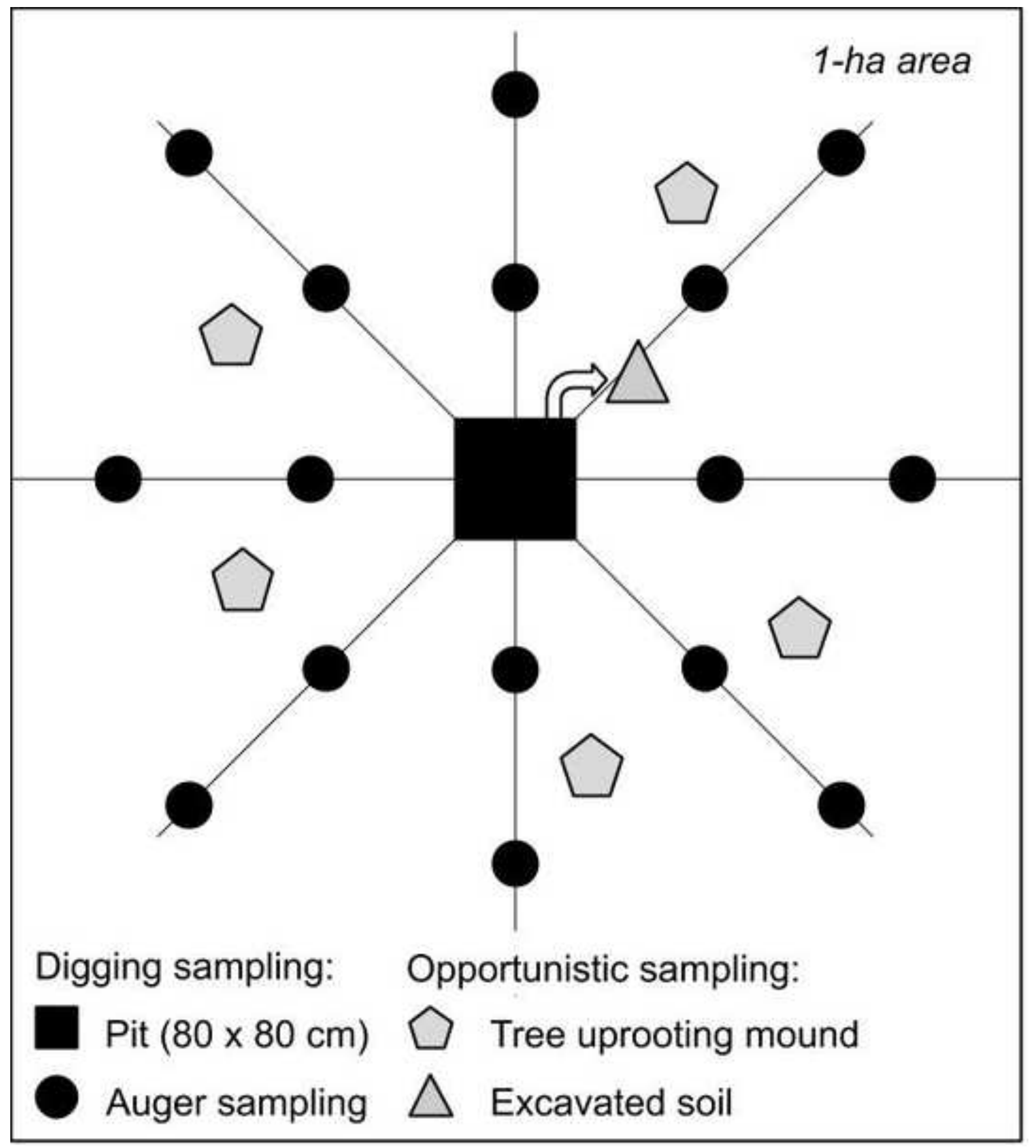




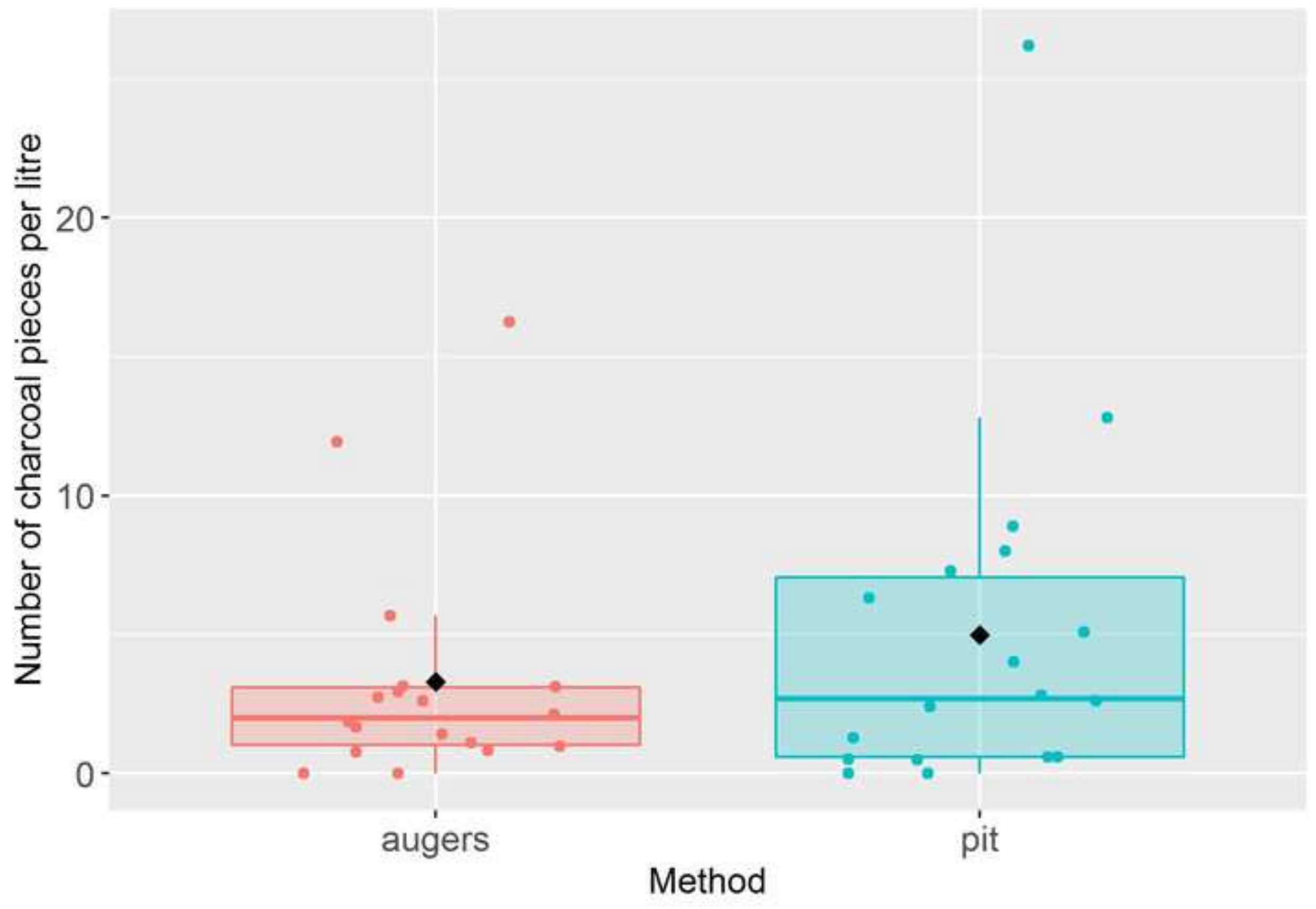



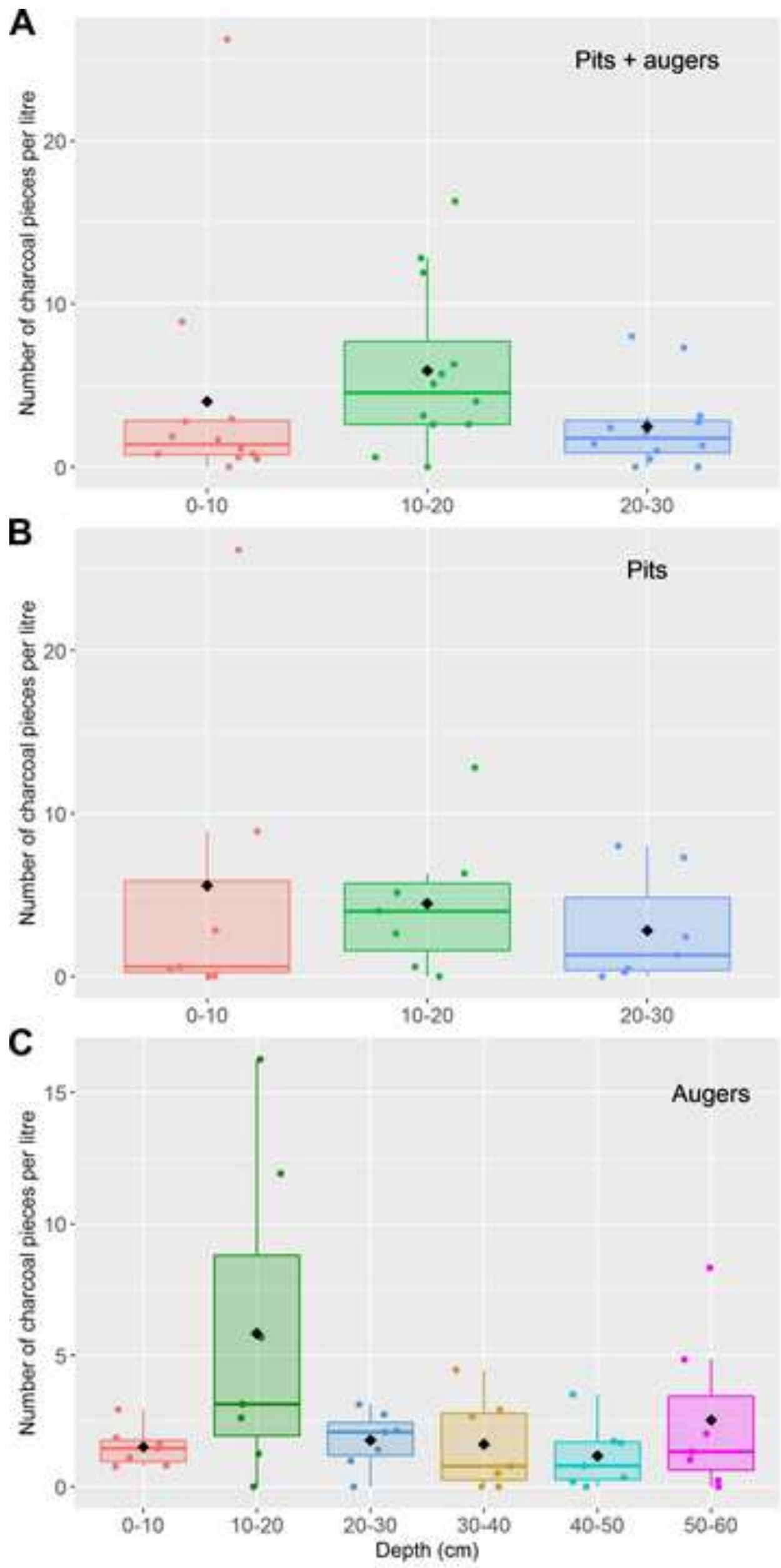

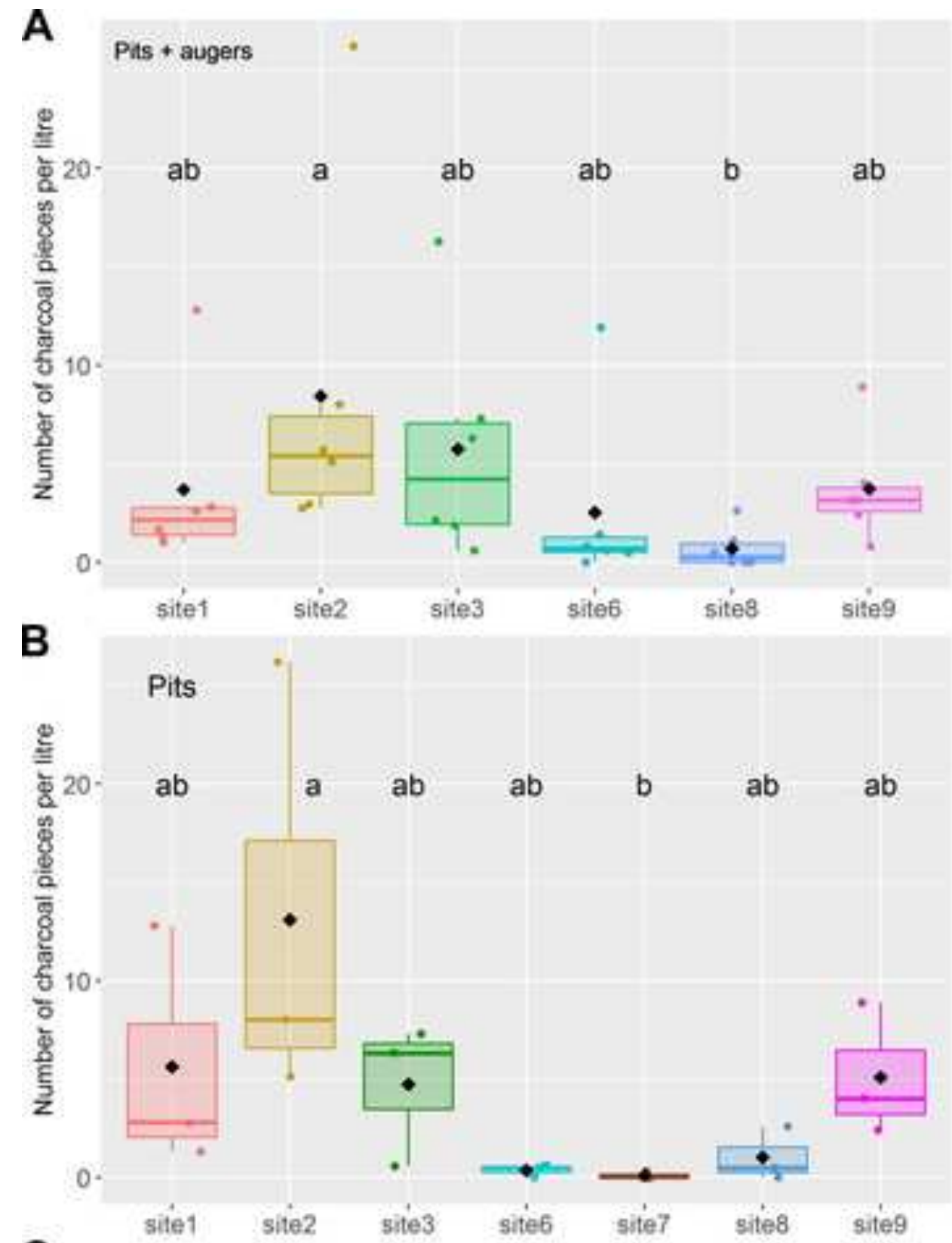

C 25- Augers

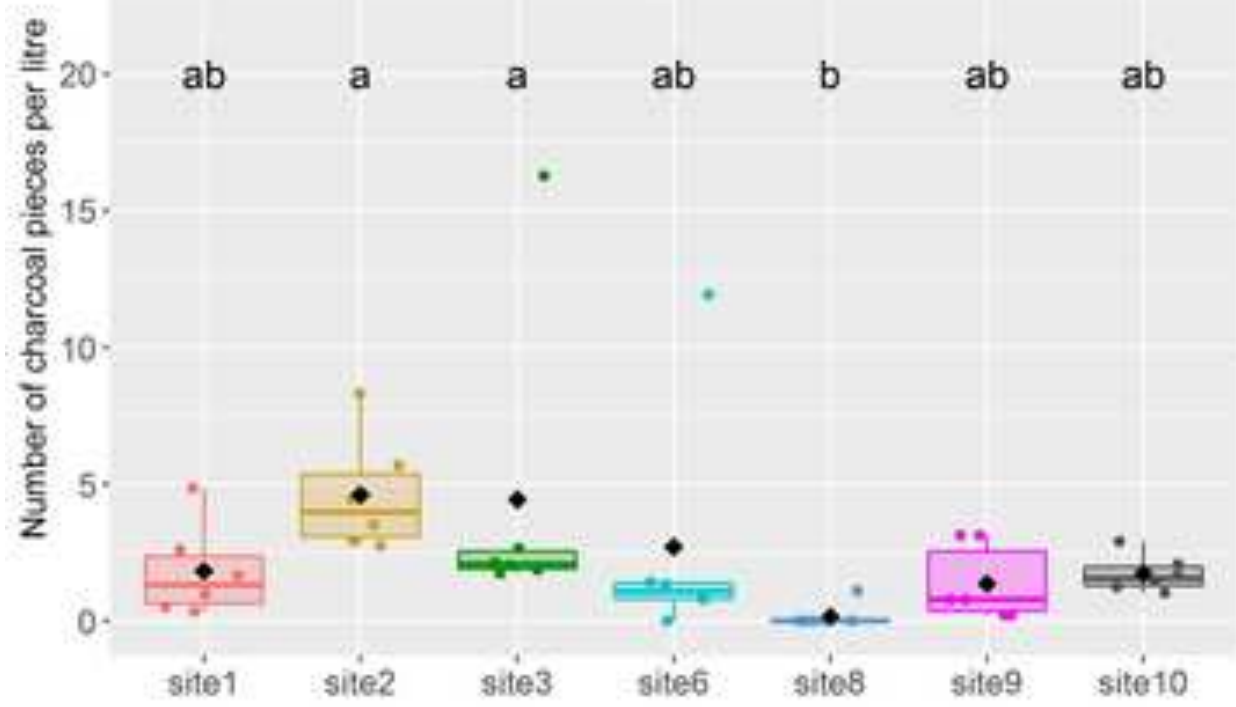



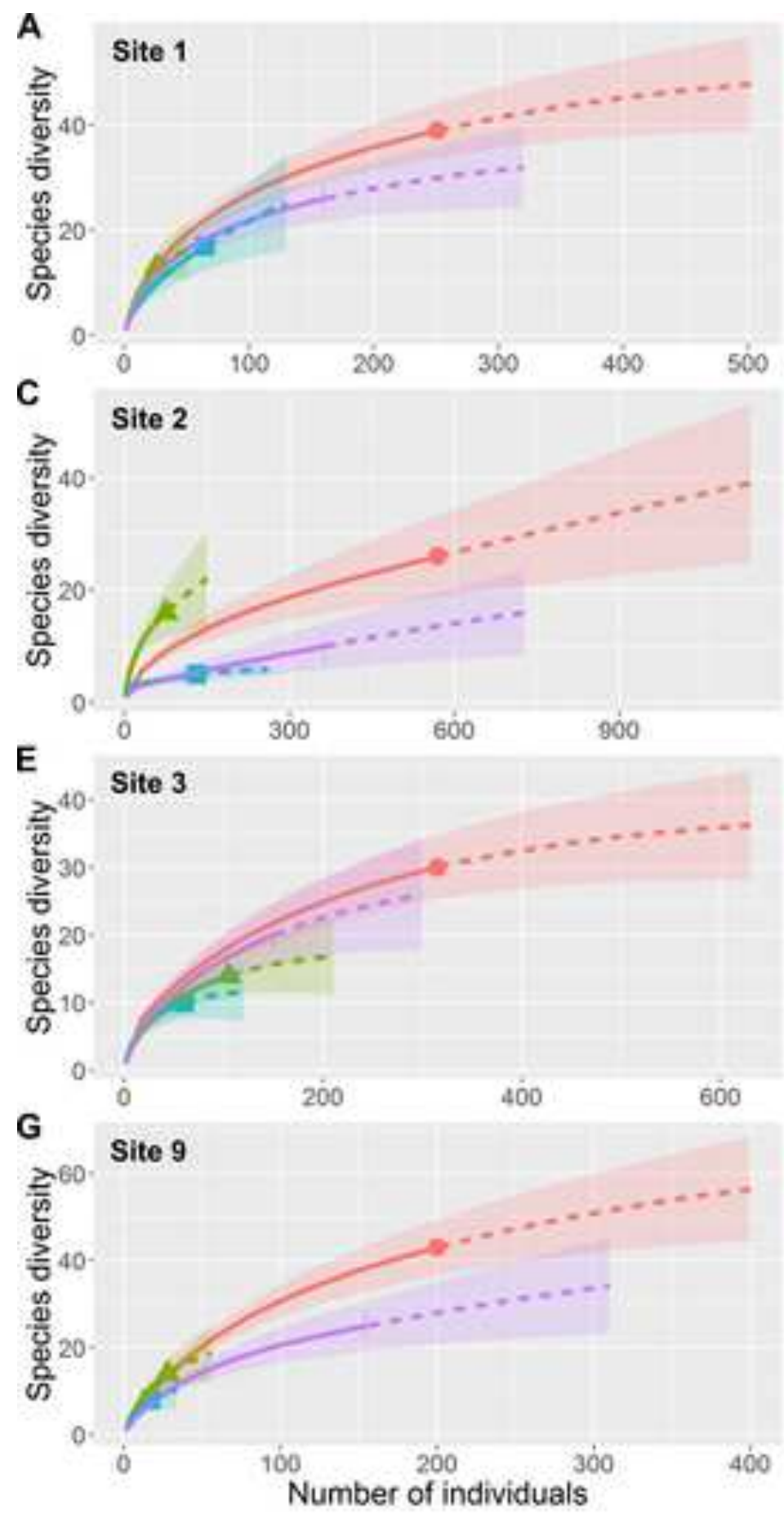

H ${ }^{30-}$ Site 9

F $30 \cdot$ Site 3
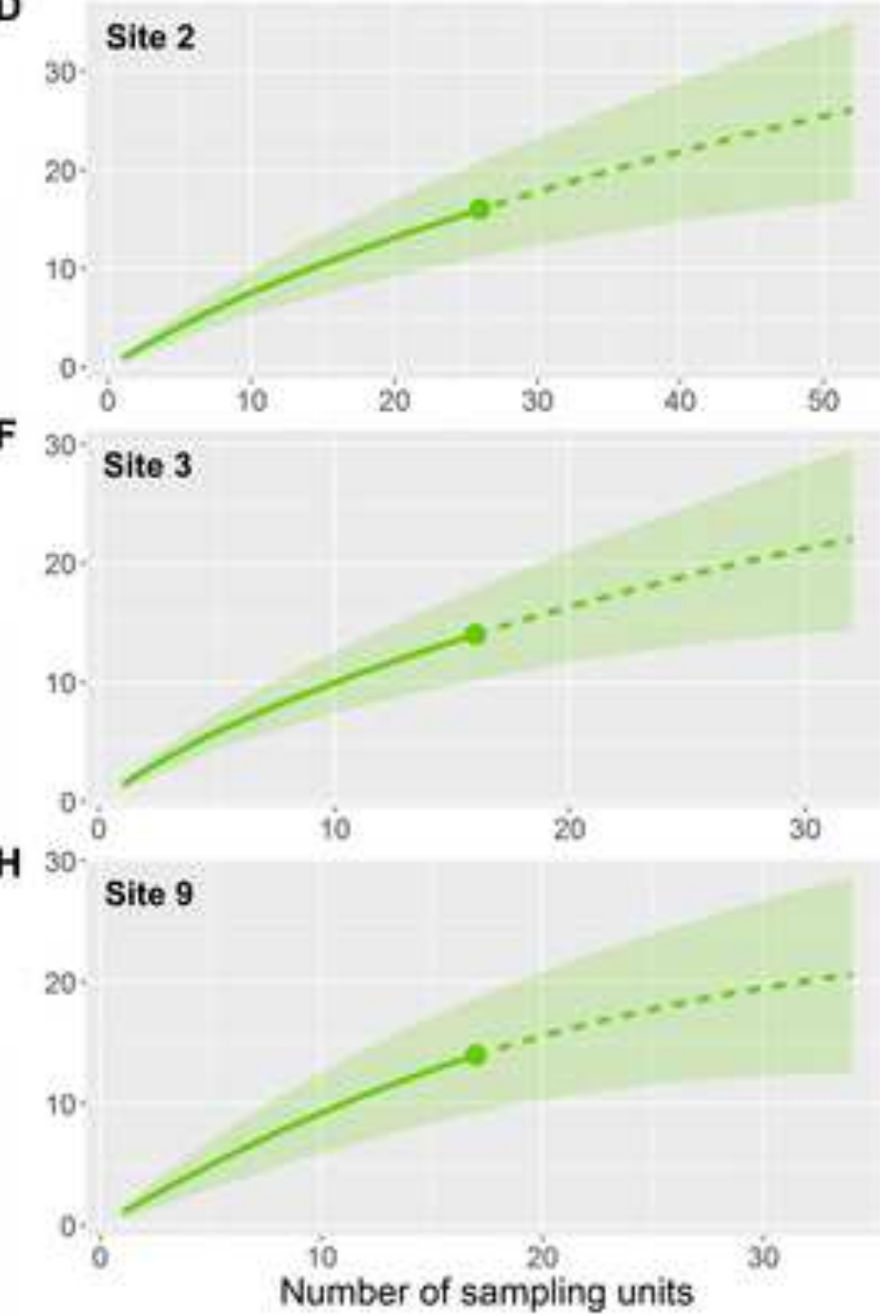

- interpolated -...extrapolated

- interpolated - - - extrapolated

Ali - A Augers - - Mounds $\longrightarrow$ Pit

B 25. Site 1

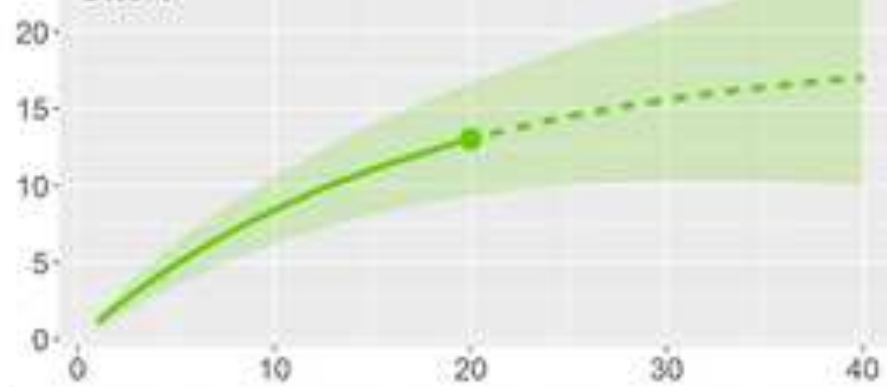

Dite 2 


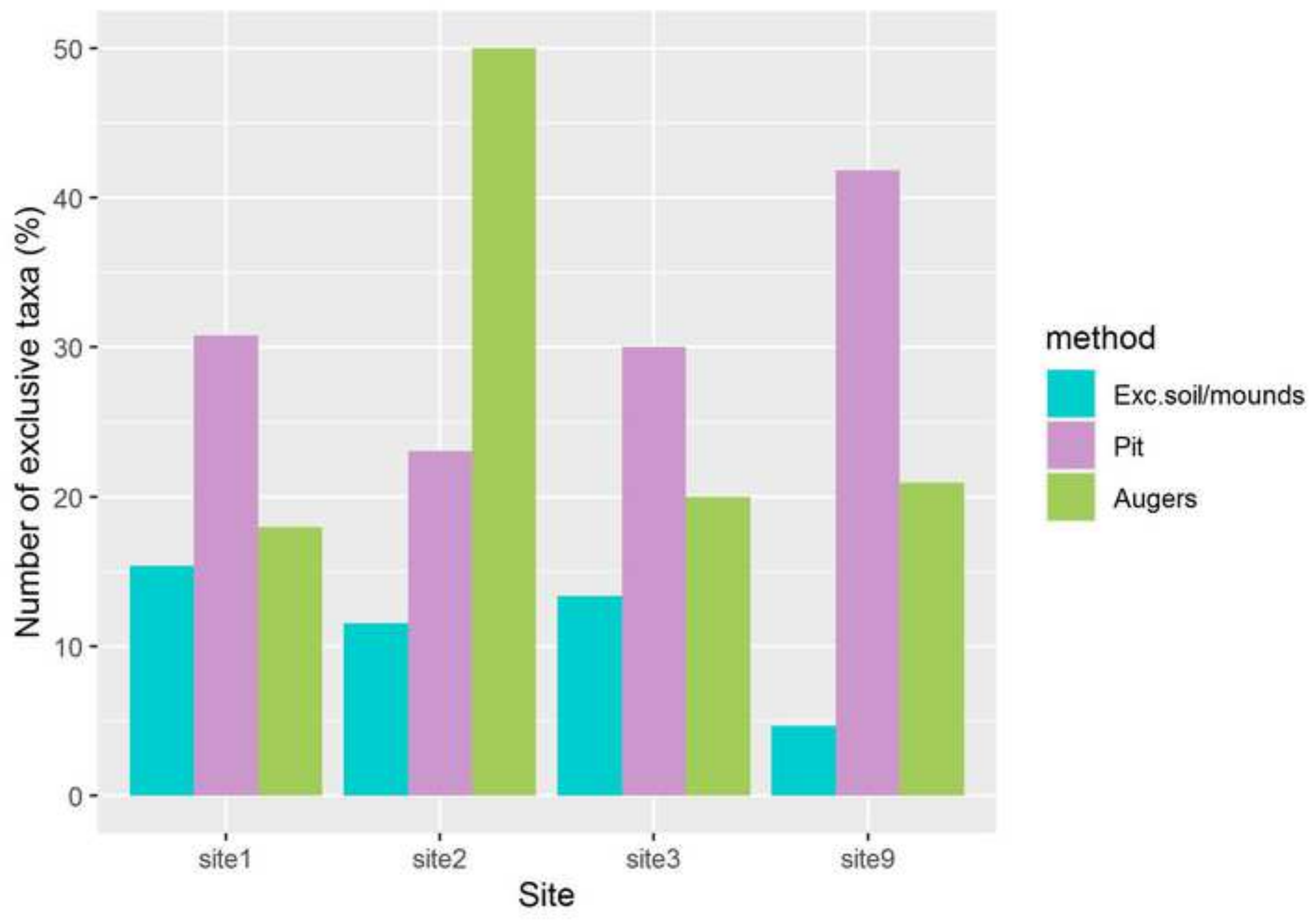




\section{Captions}

Figure 1: Sampling design representing the different sampling methods used for the recovery of charcoal in this study. Distance between auger samplings differed between sites depending on vegetation and archaeological limitations. The spacing between samples was managed to cover a 1-hectare area. The soil excavated during the digging of the pit and tree uprooting mounds were searched for charcoal fragments in some sites. As charcoals were searched with the naked eye with these two methods, they are considered opportunistic.

Figure 2: Charcoal concentrations with pit and auger sampling methods. Black diamonds indicate the means.

Figure 3: Charcoal concentrations in different sampling levels, for pit and auger sampling methods together (A); pit sampling alone (B); auger method alone (C). Black diamonds indicate the means.

Figure 4: Charcoal concentrations in sites investigated with pit and auger sampling methods (A); pit method only (B) and auger method only $(\mathbf{C})$. Letters in diagrams indicate significant differences between sites according to the Conover test (A) and to the exact all-pairs comparisons test (B and $\mathbf{C}$ ). Black diamonds indicate the means.

Figure 5: Rarefaction curves with 95\% confidence intervals for the most charcoal-rich sites 1, 2, 3, and 9 according to each sampling method and to all methods together ("All"). Left panel: individual-based rarefaction curves; right panel: sample-based rarefaction curves (sampling unit = one auger core). $\mathbf{A}$ and $\mathbf{B}$ : site 1; C and $\mathbf{D}$ : site 2; $\mathbf{E}$ and $\mathbf{F}$ : site 3; $\mathbf{G}$ and $\mathbf{H}$ : site 9.

Figure 6: Percentage of the total number of taxa recovered exclusively by a sampling method at sites 1, 2, 3 and 9. 